Article

\title{
Identification of a Novel Semi-Dominant Spotted-Leaf Mutant with Enhanced Resistance to Xanthomonas oryzae pv. oryzae in Rice
}

\author{
Zheng Chen ${ }^{1,2}$, Ting Chen ${ }^{1}$, Atul Prakash Sathe ${ }^{1}$, Yuqing He ${ }^{2}$, Xiao-bo Zhang ${ }^{1, *}$ and \\ Jian-li $\mathrm{Wu}^{1, *(1)}$ \\ 1 State Key Laboratory of Rice Biology, China National Rice Research Institute, Hangzhou 310006, China; \\ chenzheng7@126.com (Z.C.); chenting218@163.com (T.C.); atulsathe@163.com (A.P.S.) \\ 2 College of Life Science and Technology, Huazhong Agricultural University, Wuhan 430070, China; \\ yqhe@mail.hzau.edu.cn \\ * Correspondence: zhangxiaobo@caas.cn (X.-b.Z.); wujianli@caas.cn (J.-1.W.); \\ Tel.: +86-571-63370326 (X.-b.Z. \& J.-l.W.)
}

Received: 19 October 2018; Accepted: 22 November 2018; Published: 27 November 2018

\begin{abstract}
Many spotted-leaf mutants show enhanced disease resistance to multiple pathogen attacks; however, the mechanisms are largely unknown. Here, we reported a novel semi-dominant spotted-leaf mutant 24 (spl24) obtained from an ethyl methane sulfonate (EMS)-induced IR64 mutant bank. spl24 developed tiny brown lesions on the leaf tip and spread down gradually to the leaf base as well as the sheath at the early heading stage. The performances of major agronomic traits such as the plant height, panicle length, number of panicles/plant, and 1000-grain weight were significantly altered in spl24 when compared to the wild-type IR64. Furthermore, spl24 exhibited a premature senescing phenotype with degeneration of nuclear acids, significantly reduced soluble protein content, increased level of malonaldehyde (MDA), and lowered activities of reactive oxygen species (ROS) scavenging enzymes. Disease evaluation indicated that spl24 showed enhanced resistance to multiple races of Xanthomonas oryzae pv. oryzae, the causal pathogen of bacterial leaf blight in rice, with elevated expression of pathogenesis-related genes, salicylic acid (SA) signaling pathway-associated genes revealed by real-time quantitative PCR and high-throughput RNA sequencing analysis. Genetic analysis and gene mapping indicated that the lesion mimic phenotype was controlled by a novel semi-dominant nuclear gene. The mutation, tentatively termed as OsSPL24, was in a $110 \mathrm{~kb}$ region flanked by markers Indel-33 and Indel-12 in chromosome 11. Together, our data suggest that spl24 is a novel lesion mimic mutant with enhanced innate immunity and would facilitate the isolation and functional characterization of the target gene.
\end{abstract}

Keywords: rice; spotted-leaf; bacterial leaf blight; phytohormone; defense response

\section{Introduction}

Rice (Oryza sativa L.) is the major staple food for more than half of the world's population. Safe production of rice grains is largely relied on the disease resistance levels of commercial varieties. Thus, allele mining for high level of resistance to multiple rice pathogens remains critical to rice breeders. The rice spotted-leaf or lesion mimic mutant, which spontaneously forms lesions similar to the hypersensitive response (HR) lesions in leaves, leaf sheaths and stems without obvious abiotic/biotic stresses, is one of the best sources for the elucidation of disease resistance mechanism and a potential donor for improvement of rice varieties [1].

Till now, more than 80 rice spotted-leaf mutants have been identified genetically [1,2], most of these mutants are controlled by a single recessive gene, while a few of them are governed by a 
dominant/semi-dominant gene or double genes. Among these mutants, spl30 generates red-brown lesions without detectable cell death probably due to the accumulation of unknown pigments [3]. Except spl30, the other spotted-leaf mutants exhibit necrotic lesions with accumulation of reactive oxygen species (ROS) and cell death at/around the lesions [2,4,5]. So far, approximately 20 spotted-leaf genes have been isolated and characterized. Among them, spl7 is the first cloned gene which encodes a heat shock transcriptional factor and involves in regulating the expression of other heat shock transcriptional factors associated with programmed cell death [6]. Spl11 encodes an E3 ubiquitin ligase participating in the ubiquitination of unwanted proteins for $26 \mathrm{~S}$ proteasome-mediated degradation [7]. OsLCD1 encodes a zinc finger protein which plays the role not only in cell death but also the differentiation of calli [8]. In fact, the spotted-leaf gene-encoded products are very diversified in structures and functions and involved in nearly all aspects of life process. Broadly, these products can be classified into three categories: The first group is proteins, such as pathogenesis-related proteins involved in salicylic acid (SA) signaling pathway [9,10], CC-NB-LRR proteins responsible for innate immunity [11], eukaryotic release factor [12], eukaryotic translation elongation factor [13], RNA splicing factor [14,15], membrane-associated proteins [16,17], ion channel regulators [18] as well as clathrin-associated protein [19]. The second group is enzymes, consisting of lipid kinase [20], oxidoreductase [21], acyltransferase [22], protein kinase and mitotic-activated related kinase [23,24], cytochrome p450 monooxygenase and catalase [25], AAA-ATPase [26], and E3 ubiquitin ligase [7,27]. The third group is compounds such as fatty acids/lipids, porphyrin, and phenolic compounds [28]. The diversity and complexity of spotted-leaf gene products indicate extreme complicated mechanisms underlying the formation of leaf lesions. Therefore, identification of novel spotted-leaf mutants would be helpful and accelerate the elucidation of their molecular mechanisms for lesion formation and enhanced/decreased disease resistance.

Most of the spotted-leaf mutants show enhanced disease resistance to various major rice pathogens. Extensive studies have shown that at least 68 mutants exhibit an enhanced level of resistance to at least one type of pathogen, and 28 mutants show enhanced resistance to two types of pathogens. In fact, several mutants exhibit a broad-spectrum resistance to multiple pathogens such as Xanthomonas oryzae pv. oryzae (Xoo) and Magnaporthe oryzae [7,29] while some mutants show broad-spectrum resistance to multiple races/strains of a pathogen $[5,7,30]$. The enhancement of defense responses is often accompanied by the outburst of ROS and programmed cell death (PCD) $[19,22,24,30]$. Interestingly, ROS-triggered defense responses are often accompanied by leaf senescence which allows nutrient remobilization [19]. Furthermore, elevated expression of defense response-associated genes involved in SA, jasmonic acid (JA), abscisic acid (ABA) and ethylene (ET) signaling pathways has been observed and validated in several studies [12,31].

Here, we identified a rice spotted-leaf 24 (spl24) mutant from an EMS-induced IR64 (an elite indica cultivar) mutant bank. We compared the major agronomic traits, analyzed the histochemical indicators of PCD, measured the levels of chlorophylls, soluble proteins and phytohormones, evaluated the disease reaction to Xoo, conducted the expression analysis of defense-related genes, and determined the genetic control of the spotted-leaf phenotype. Our results demonstrated that $s p l 24$ is a novel spotted-leaf mutant with enhanced disease resistance to multiple races of Xoo probably by activating the SA signaling pathway. The mutation is controlled by a semi-dominant gene (tentatively termed as OsSPL24) located to the long arm of the chromosome 11. The data obtained in the present study would facilitate the map-based cloning of OsSPL24 and functional analysis of the mutation underlying the formation of lesions.

\section{Results}

\subsection{Performance of Agronomic Traits}

Under the natural summer conditions, the tiny brown lesions/spots first appeared on the leaf tips of spl24 and spread down to the whole leaf blades approximately 13 weeks after sowing in the 
paddy field at the China National Rice Research Institute (CNRRI), Hangzhou, China. The leaves gradually turn into dark brown with the increasing number of lesions which also appeared on the surface of some husks in the mutant at the heading stage (Figure 1A-D). At the tillering stage, the level of chlorophyll a (Chl a) was significantly different between spl24 and the wild-type IR64 (WT), while the levels of chlorophyll $\mathrm{b}(\mathrm{Chl} b)$, carotenoid and $\mathrm{Chl} \mathrm{a} / \mathrm{b}$ ratio were similar between the two genotypes (Figure 1E). At the heading stage, the levels of $\mathrm{Chl} \mathrm{a,} \mathrm{Chl} \mathrm{b} \mathrm{and} \mathrm{carotenoid} \mathrm{were} \mathrm{all}$ decreased significantly in spl24 compared with WT, while the ratio of $\mathrm{Chl}$ a/b was similar (Figure 1F), indicating that the loss of photosynthetic pigments may be due to a reduction of the total number of living cells containing chloroplasts because of the necrotic lesions. Furthermore, the level of soluble proteins was sharply decreased in spl24 compared with WT at the heading stage probably due to the same reason mentioned above (Figure 1G). The performance of major agronomic traits including the plant height, number of tillers/plant, panicle length, number of tillers/panicle, seed-setting rate, and 1000-grain weight were significantly altered in the mutant when compared to WT (Table 1). Taken together, our data suggested that the mutation induced the formation of brown lesions with decreasing levels photosynthetic pigments and soluble proteins especially at the heading stage and ultimately led to the altered performance of major agronomic traits in the mutant.
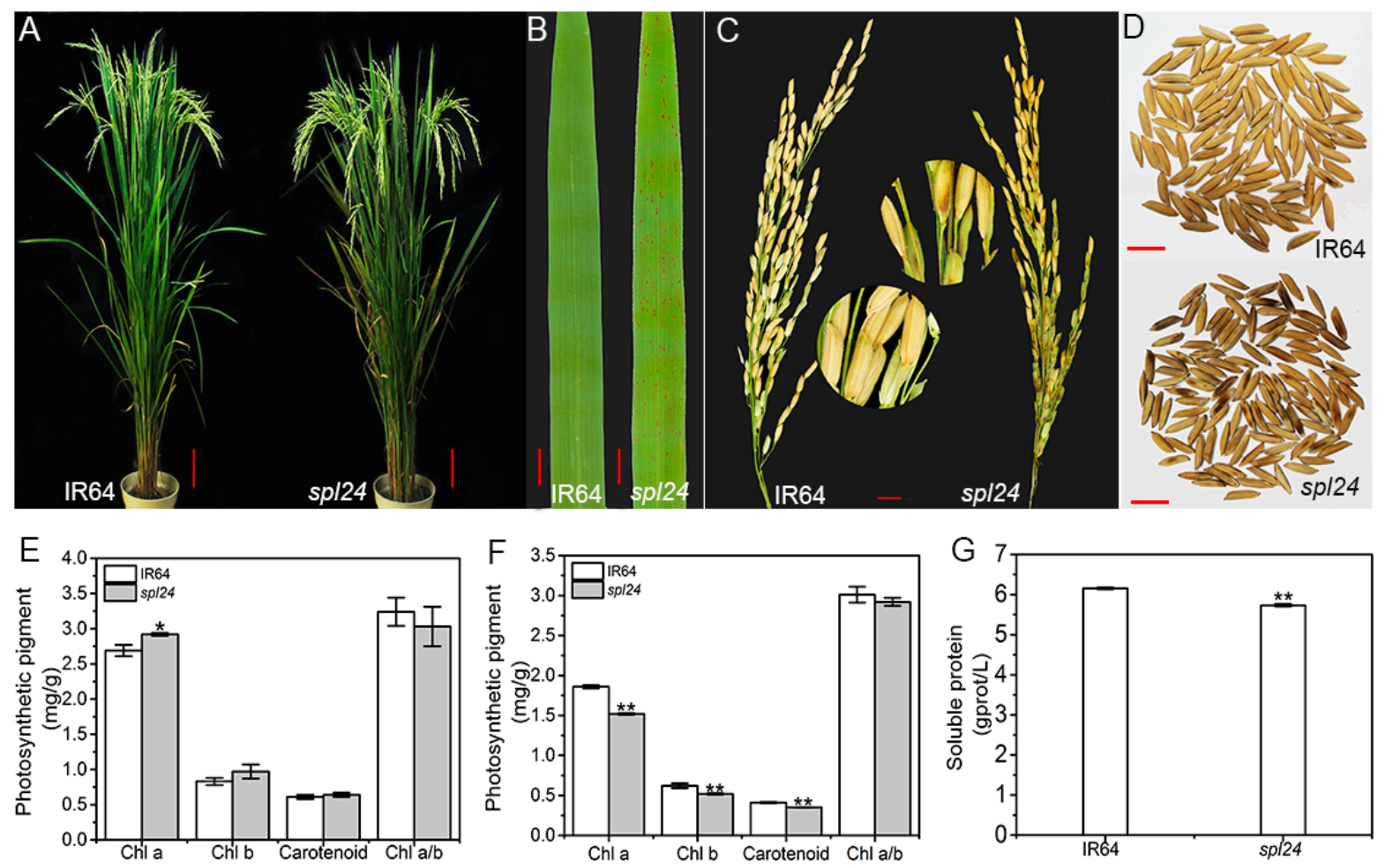

Figure 1. Phenotypic characteristics of spl24 and the wild-type IR64. (A) Mature plant, bar $=10 \mathrm{~cm}$; (B) Leaf of IR64 and spl24; bar = $1 \mathrm{~cm}$; (C) panicle of IR64 and spl24, bar = $1 \mathrm{~cm}$; (D) grains of IR64 and spl24; bar = $1 \mathrm{~cm}$; (E) photosynthetic pigment contents of IR64 and spl24 at the tillering stage; (F) photosynthetic pigment contents of IR64 and spl24 at the heading stage; (G) soluble protein content of IR64 and spl24 at the heading stage. Values are means $\pm \operatorname{SD}(n=3) ;{ }^{* *}$ indicates significance at $p \leq 0.01$ and ${ }^{*}$ indicates significance at $p \leq 0.05$ by Student's $t$ test. 
Table 1. Performance of agronomic traits in IR64 and spl24.

\begin{tabular}{ccccccc}
\hline Material & $\begin{array}{c}\text { Plant Height } \\
\mathbf{( c m )}\end{array}$ & $\begin{array}{c}\text { No. } \\
\text { Tiller/Plant }\end{array}$ & $\begin{array}{c}\text { Panicle } \\
\text { Length } \mathbf{( c m})\end{array}$ & $\begin{array}{c}\text { No. Filled } \\
\text { Grain/Panicle }\end{array}$ & $\begin{array}{c}\text { Seed-Setting } \\
\mathbf{( \% )}\end{array}$ & $\begin{array}{c}\text { 1000-Grain } \\
\text { Weight }(\mathbf{g})\end{array}$ \\
\hline IR64 & $117.0 \pm 0.5$ & $19.3 \pm 3.2$ & $26.4 \pm 0.2$ & $58.0 \pm 3.6$ & $50.4 \pm 1.1$ & $24.3 \pm 0.2$ \\
spl24 & $109.8 \pm 1.3^{* *}$ & $28.0 \pm 1.0^{*}$ & $25.6 \pm 0.6^{*}$ & $69.3 \pm 2.5^{*}$ & $55.6 \pm 0.6^{* *}$ & $22.9 \pm 0.3^{* *}$ \\
\hline
\end{tabular}

Values are means $\pm \mathrm{SD}(n=3) ;{ }^{* *}$ indicates significance at $p \leq 0.01$ and ${ }^{*}$ indicates significance at $p \leq 0.05$ by Student's $t$ test.

\subsection{Impaired Function of Photosynthetic Capacity}

Although the ratio of $\mathrm{Chl}$ a/b was normal, the lowered chlorophyll level in spl24 at the heading stage might affect the photosynthetic capacity in the mutant as shown by the altered performance of agronomic traits (Table 1). To examine the photosynthetic capacity, we measured the photosynthetic parameters of leaves in WT and spl24 at the heading stage. Our results showed that the net photosynthetic rate $(P n)$, stomatal conductance $(G s)$ and transpiration rate (Tr) were significantly lower in spl24 than those of WT (Figure 2A-C), while the intercellular $\mathrm{CO}_{2}$ concentration (Ci) was similar between spl24 and IR64 (Figure 2D). These results suggested that the lowered chlorophyll level indeed resulted in a lower photosynthetic capacity leading to the altered performance of agronomic traits in spl24.
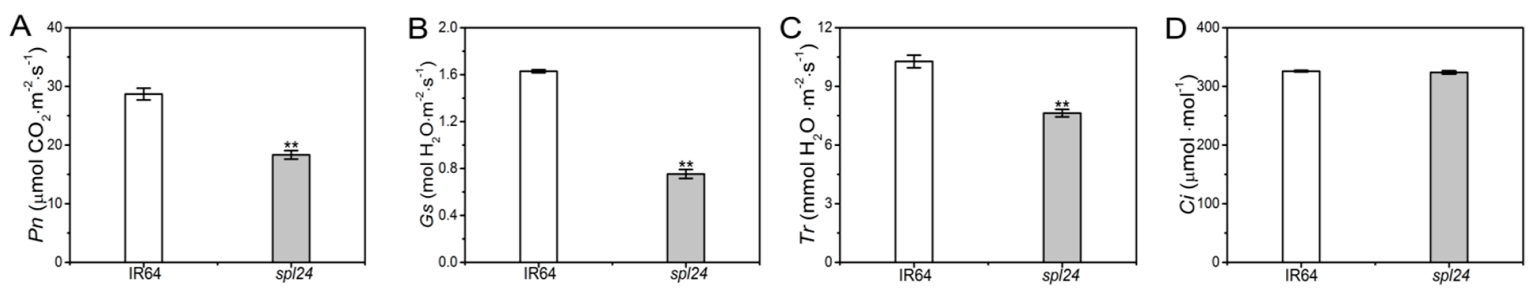

Figure 2. Photosynthetic parameters of leaves at the heading stage. (A) Net photosynthetic rate $(P n)$; (B) stomatal conductance (Gs); (C) transpiration rate (Tr); (D) intercellular $\mathrm{CO}_{2}$ concentration (Ci). Values are means $\pm \operatorname{SD}(n=3) ;{ }^{* *}$ indicates significance at $p \leq 0.01$ by Student's $t$ test.

\subsection{Lesion Initiation Is Light-Dependent}

Many lesion mimic mutants are light-dependent on the initiation of lesions [1]. To determine the effect of light on spl24 lesion formation under the natural field conditions, the newly emerged leaves of spl 24 without lesions were covered with $2 \mathrm{~cm}$ aluminum foil for 7 days. The results showed that the shaded leaf area of spl24 remained green without lesions similar to WT while the unshaded area had brown lesions after 7-day shading treatment (Figure 3A-D). The foil then was removed, and the light was reinstated, a few brown lesions appeared in the shaded leaf area 5 days and a large number of brown lesions appeared 15 days after removal of the foil (Figure 3E,F). No obvious changes were observed before and after shading treatment in WT (Figure 3). These results suggested that the initiation of brown lesions in the mutant was light-dependent.

\subsection{ROS-Associated Cell Death Occurs in spl24}

To determine whether cell death occurred at/around the lesions, we first carried out trypan blue staining, a traditional method for selective staining of dead cells and irreversible membrane damage [19]. The results exhibited that dark blue stains were observed at/around the lesions in spl24 while no blue stains were detected at/around lesions in WT (Figure 4A), indicating that cell death indeed occurred in the mutant resembling the HR-induced lesions. 




Figure 3. Light effect on lesion formation under the natural conditions. (A) IR64; (B) spl24 before shading; (C) IR64 shaded for 7 days; (D) spl24 shaded for 7 days; (E) spl24 reinstated for 5 days; (F) spl24 reinstated for 15 days. Shaded areas are boxed. bar $=1 \mathrm{~cm}$.

To further confirm the cell death in spl24, we measured the levels of malonaldehyde (MDA) and membrane ion leakage, two cell membrane damage indicators. The results showed that the MDA content and the value of membrane ion leakage were significantly increased in spl24 at the heading stage compared with WT (Figure 4G,H). To examine whether DNA fragmentation, another indicator of cell death, happened in spl24, we carried out a terminal deoxyribonucleotidyl transferase-mediated dUTP nick-end labeling (TUNEL) assay. The results showed that a few nuclei (green) were TUNEL positive in WT, whereas a large number of nuclei were TUNEL positive in spl24 (Figure 4J). Our results demonstrated that the mutation resulted in the damage to cell membrane and induced a large-scale DNA degeneration leading to cell death as shown by trypan blue staining.

To investigate whether the cell death was associated with the burst of ROS, we first carried out the detection of $\mathrm{H}_{2} \mathrm{O}_{2}$ accumulation in the leaves by 3, 3'-Diaminobenzidine (DAB) staining [32]. The results showed that the apparent red-brown precipitate was observed at and around the lesions in mutant leaves; however, no such red-brown precipitate was observed in the wild-type (Figure 4B). We further measured the $\mathrm{H}_{2} \mathrm{O}_{2}$ content, and the results showed that the $\mathrm{H}_{2} \mathrm{O}_{2}$ content in the mutant spl24 was significantly increased compared to WT at the heading stage (Figure 4C). The results demonstrated that the appearance of brown lesions in the mutant accompanied by cell death was likely resulted from the burst of $\mathrm{H}_{2} \mathrm{O}_{2}$. The burst of ROS implies the disruption of ROS scavenging system in spl24. To test this possibility, we measured the activities of three anti-oxidative enzymes, including catalase (CAT), superoxide dismutase (SOD) and peroxidase (POD), which are usually activated to remove elevated ROS under oxidative stresses [33]. Our results showed that the CAT activity was significantly lower in spl24 than that of WT (Figure 4D) while the activities of SOD and POD were significantly increased in spl24 when compared to WT at the heading stage (Figure 4E,F). The results suggested that the ROS scavenging system was impaired and insufficient to remove the excessive ROS which ultimately led to the cell death in spl24. 

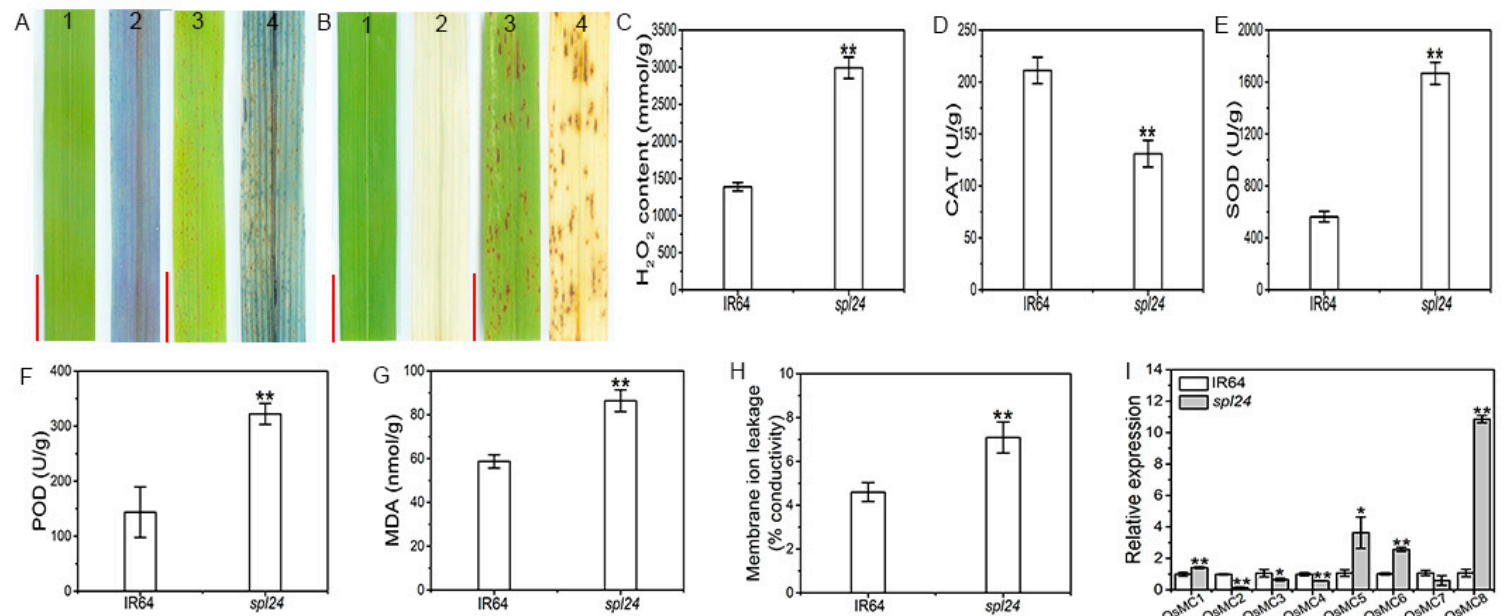

b


Figure 4. Analysis of cell death and ROS-associated parameters in IR64 and spl24. (A) Typan blue staining. 1, IR64; 2, IR64 after staining; 3, spl24; 4, spl24 after staining; bar $=1 \mathrm{~cm}$; (B) DAB staining. 1, IR64; 2, IR64 after staining; 3, spl24; 4, spl24 after staining; bar = $1 \mathrm{~cm}$; (C) $\mathrm{H}_{2} \mathrm{O}_{2}$ content at the heading stage; (D-F) the enzymatic activities of CAT, SOD, POD in the flag leaves. CAT, catalase; SOD, superoxide dismutase; POD, peroxidase; (G) malonaldehyde (MDA) contents of the flag leaves; (H) membrane ion leakage rates at the heading stage; (I) expression analysis of OsMCs at the heading stage; (J) TUNEL assay at the heading stage. Blue signal represents $4^{\prime}, 6$-diamino-phenylindole (DAPI) staining; green color represents positive result. (a) and (d) are DAPI staining; (b) and (e) are TUNEL signal; (c) and $\mathrm{f}$ are merged images of $(\mathrm{a} / \mathrm{b})$ and $(\mathrm{c} / \mathrm{d})$ respectively, bar $=100 \mu \mathrm{m}$. Values are means $\pm \mathrm{SD}$ $(n=3) ;{ }^{* *}$ indicates significance at $p \leq 0.01$ and ${ }^{*}$ indicates significance at $p \leq 0.05$ by Student's $t$ test.

It has been widely accepted that the cell death is accompanied with the altered expression of PCD-related genes [34]. To validate whether the alteration of PCD-related gene expression happened in spl24, we carried out the expression analysis of a set of eight metacaspase genes. Our results showed that the expression levels of OsMC1, OsMC5, OsMC6, and OsMC8 were significantly increased compared with WT. In contrast, the expression levels of OsMC2, OsMC3, and OsMC4 were apparently decreased compared with WT while the expression level of OsMC7 was similar to that of WT (Figure 4I). Although it is uncertain which of these metacaspase plays the critical role in PCD, our results demonstrated that the mutation in spl24 caused PCD accompanied with altered expression of metacaspase genes in the mutant.

\subsection{Enhanced Disease Resistance to Xoo with Elevated Expression of Defense Response Genes}

HR lesions prevent host plants from further invasion of virulent pathogens to nearby cells, and consequently enhance the level of disease resistance. To test whether the disease resistance level has been changed in spl24, we inoculated spl24, WT and the susceptible control IR24 using ten races of Xanthomonas oryzae pv. oryzae under the natural field conditions by a leaf-clipping method at the tillering stage. The results showed that IR24 was susceptible to all races tested while the mutant spl24 showed significantly enhanced resistance to races HB17 ( $p \leq 0.05)$, JS97-2, PXO112, Zhe173, PXO339, 
PXO347 and PXO349 $(p \leq 0.01)$ compared with WT, while the resistance level to GD1358, PXO71 and OS-225 was similar between spl24 and WT (Table 2). These results indicated that the mutant displayed a broad-spectrum resistance to multiple races of bacterial blight pathogens.

Table 2. Evaluation of disease resistance to Xanthomonas oryzae pv. oryzae.

\begin{tabular}{cccc}
\hline \multicolumn{3}{c}{ Lesion length $(\mathbf{c m})$} \\
\hline race & IR24 & IR64 & spl24 \\
\hline HB17 & $25.39 \pm 3.85$ & $5.71 \pm 1.06$ & $3.70 \pm 1.39^{*}$ \\
GD1358 & $12.87 \pm 0.51$ & $5.60 \pm 1.28$ & $4.40 \pm 1.68$ \\
PXO71 & $23.10 \pm 4.71$ & $3.05 \pm 0.33$ & $2.43 \pm 0.93$ \\
JS97-2 & $16.48 \pm 2.29$ & $12.40 \pm 1.41$ & $7.00 \pm 1.96^{* *}$ \\
PXO112 & $23.93 \pm 2.86$ & $4.82 \pm 0.88$ & $3.40 \pm 0.89^{* *}$ \\
Zhe173 & $19.98 \pm 3.07$ & $7.01 \pm 1.02$ & $4.80 \pm 1.43^{* *}$ \\
OS-225 & $14.32 \pm 2.92$ & $2.41 \pm 0.67$ & $2.40 \pm 0.57$ \\
PXO339 & $22.14 \pm 2.32$ & $16.63 \pm 2.01$ & $9.20 \pm 1.95^{* *}$ \\
PXO347 & $21.40 \pm 3.67$ & $18.15 \pm 2.11$ & $10.10 \pm 1.66^{* *}$ \\
PXO349 & $17.68 \pm 2.71$ & $13.17 \pm 1.80$ & $9.40 \pm 2.20^{* *}$
\end{tabular}

Values are means $\pm \mathrm{SD}(n=3) ;{ }^{* *}$ indicates significance at $p \leq 0.01$ and ${ }^{*}$ indicates significance at $p \leq 0.05$ by Student's $t$ test.

Increased levels of disease resistance are often associated with up-regulated expression of defense response genes [29]. To determine the correlations between the enhanced resistance level to Xoo and the expression level of defense response genes in the mutant, 14 defense response genes either involved in SA or JA signaling pathway were tested by real-time quantitative PCR analysis. The results indicated that the transcriptional levels of six genes (OsJAR1, OsAOS2, OsWRAKY45, OsJAZ6, OsJamyb, and OsPAD4) involved in JA signaling pathway and eight genes (OsPR1a, OsPR1b, OsPR3, OsPR4, OsPAL3, OsPAL6, OsCHS1, and OsEDS1) involved in SA signaling pathway were apparently increased in spl24 compared with WT (Figure 5A,B). The results clearly demonstrated that the enhanced level of disease resistance was associated with the up-regulated expression of the defense response genes in spl24.
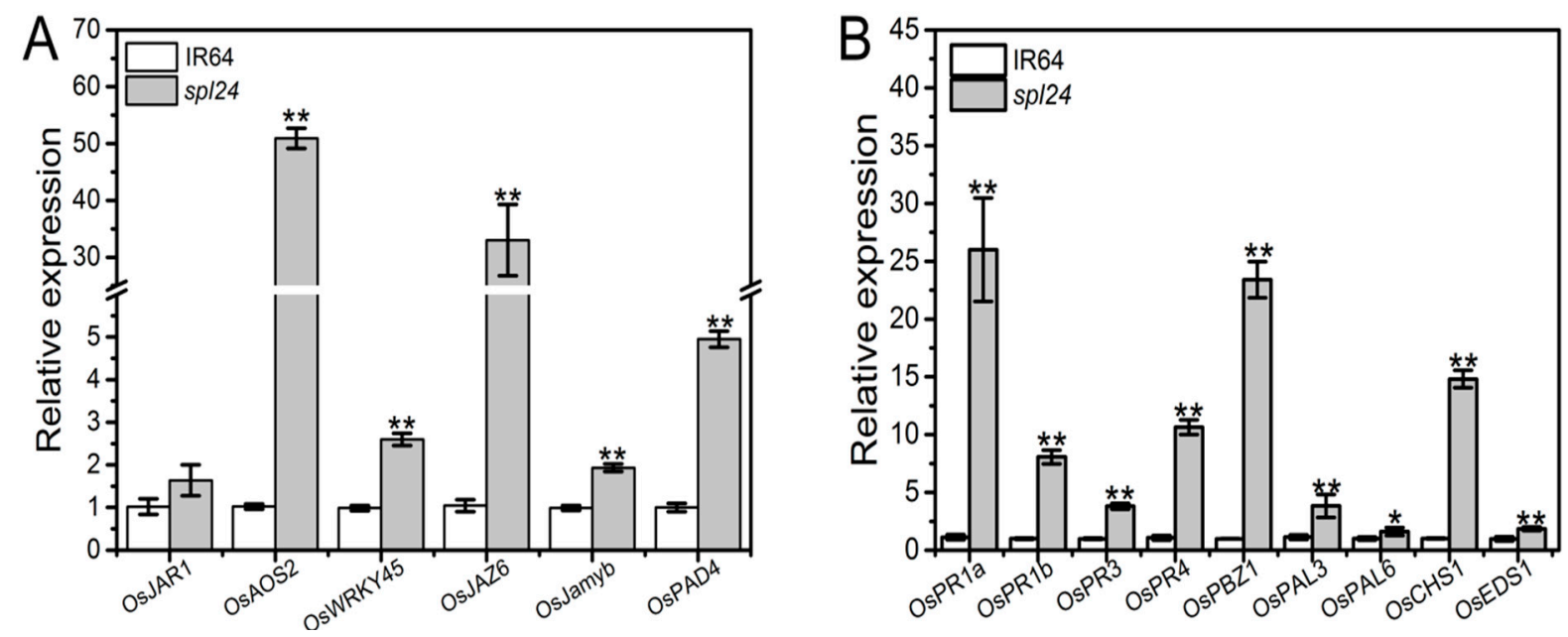

Figure 5. Quantitative PCR analysis of defense response genes involved in JA and SA signaling pathways. (A) Expression analysis of genes in JA pathway at the heading stage; (B) expression analysis of genes in SA pathway. The expression level of each gene in the wild-type was normalized to 1 . Values indicate means $\pm \operatorname{SD}(n=3)$. ${ }^{*}$ denotes $P \leq 0.05$, and ${ }^{* *}$ denote $p \leq 0.01$ by Student's $t$ test. 


\subsection{SPL24-Mediated Disease Resistance Is Associated With the Activation of SA Signaling Pathway}

We have shown that spl24 enhanced resistance to Xoo is associated with the activation of defense response genes involved in both JA and SA signaling pathways. To further explore the potential resistance mechanism, we carried out high-throughput mRNA sequencing (RNA-seq) analysis. The cDNA libraries were prepared both from the leaves of $3 \mathrm{BC}_{2} \mathrm{~F}_{2}-\mathrm{S}$ (spl24-like plant) and the $\mathrm{BC}_{2} \mathrm{~F}_{2}-\mathrm{W}$ (IR64-like plant) individual plants. The results showed that a total of 3420 differentially expressed genes (DEGs) were identified between spl24-like plants and IR64-like plants. Among them, 1860 genes were up-regulated, and 1560 genes were down-regulated in the spl24-like plants. Five SA signaling pathway-associated genes including OsPR1a (LOC_Os07g03710), OsPR1b (LOC_Os01g28450), OsPR3 (LOC_Os04g41620), OsPR4 (LOC_Os11g37970) and OsPBZ1 (LOC_Os12g36880) were significantly up-regulated by 3.63-, 2.80-, 9.56-, 7.06- and 2.70-fold, respectively (Supplementary Dataset S1). In addition, the other defense marker genes involved in SA signaling pathways were all up-regulated (Supplementary Dataset S1). These results were similar to those in qRT-PCR. Unlike qRT-PCR analysis, the genes involved in JA signaling pathway were not detected in RNA-seq analysis. Nevertheless, our results suggested that enhanced disease resistance in spl24 was likely resulted from the activation of SA signaling pathway.

We then performed Gene Ontology (GO) analysis to classify the functions of the 3420 DEGs identified in spl24-like plants. The GO term enrichment indicated that the 3420 DEGs could be classified into $29 \mathrm{GO}$ terms under three biological processes with $p \leq 0.01$. Among them, $4 \mathrm{GO}$ terms belong to Functional process, one term belongs to Biosynthetic process, and 24 terms belong to Component process (Supplementary Dataset S2, Total). For the 1860 up-regulated genes, a total of 23 GO terms were assigned, among them, "cytoplasmic membrane-bounded vesicle", "cytoplasmic vesicle", "membrane-bounded vesicle" and "vesicle" were the four most enriched and distinguished terms with $p$-values of $1.34 \times 10^{-21}, 1.34 \times 10^{-21}, 1.95 \times 10^{-21}$ and $2.30 \times 10^{-21}$, respectively (Supplementary Dataset S2, Up-regulated). For the 1560 down-regulated DEGs, a total of 49 GO terms were assigned, among them, "ribosomal subunit", "cytosolic ribosome" and "cytosolic part" were the three most enriched and distinguished terms with $p$-values of $8.34 \times 10^{-39}, 1.53 \times 10^{-38}$ and $1.06 \times 10^{-37}$, respectively (Supplementary Dataset S2, Down-regulated). It has been shown that the secretory transport molecules generated by endoplasmic reticulum are harmful to microorganisms including pathogens. Thus, vesicle trafficking might play a critical role in the perception of PAMP during pathogen infections. Previous studies have indicated that extracellular secretory vesicle tethers can be mediated by an extracellular foam complex subunit named Exo70B2 and these vesicle tethers exhibit the immunity function against various pathogens [35,36]. Therefore, based on the results of GO enrichment, we infer that the enhanced disease resistance of spl24 mutant is probably related to the vesicle trafficking.

To further explore the biological pathways in which spl24 may be involved, we performed KEGG enrichment analysis for the 3420 DEGs between the spl24-like and IR64-like plants. The results showed that all the DEGs were classified into 11 pathways (Supplementary Dataset S3, Total). The up-regulated 1860 DEGs enriched in 19 significantly pathways $(P \leq 0.01)$, among them, "Phenylalanine metabolism", "Biosynthesis of secondary metabolites" and "Isoquinoline alkaloid biosynthesis" were the most enriched and distinguished pathways with $p$-values of $2.09 \times 10^{-6}, 1.05$ $\times 10^{-5}$ and $1.26 \times 10^{-5}$, respectively (Supplementary Dataset S3, Up-regulated), while the 1560 down-regulated DEGs were grouped into six predominant pathways, among them, "Ribosome", "Ribosome biogenesis in eukaryotes" and "Phenylpropanoid biosynthesis" were the most enriched and significant pathways with $p$-values of $2.82 \times 10^{-41}, 0.004$ and 0.026 , respectively (Supplementary Dataset S3, Down-regulated). These results suggest that spl24-mediated disease resistance is likely associated with protein translation and defense response, consistent with the results of GO enrichment.

To further understand the association of spl24-mediated resistance and the endogenous hormone levels, we determined the levels of various hormones in the leaves of spl24-like and IR64-like plants. For the sake of easy comparison, the content of various endogenous hormones in the wild-type 
IR64 was set to 1, and the relative content of endogenous hormone in spl24 was shown in Figure 6. The results showed that the contents of SA, JA, and ABA in the spl24 were significantly increased by $23.2 \%, 62.5 \%$ and $49.7 \%$ compared to WT, respectively, whereas the IAA level was similar between the two genotypes, indicating that the broad-spectrum resistance of spl24 was probably resulting from the activation of phytohormone-mediated pathway. Furthermore, ABA is involved in the ROS-mediated PCD [31], the increased level of ABA might contribute to the occurrence of PCD in spl24 as shown by the positive TUNEL assay, ROS measurement and metacaspase gene expression analysis. As the up-regulated gene expression in SA signaling pathway was detected both in qRT-PCR and RNA-seq, we concluded that the enhanced resistance of spl24 to Xoo was most likely resulted from the activation of SA signaling pathway.

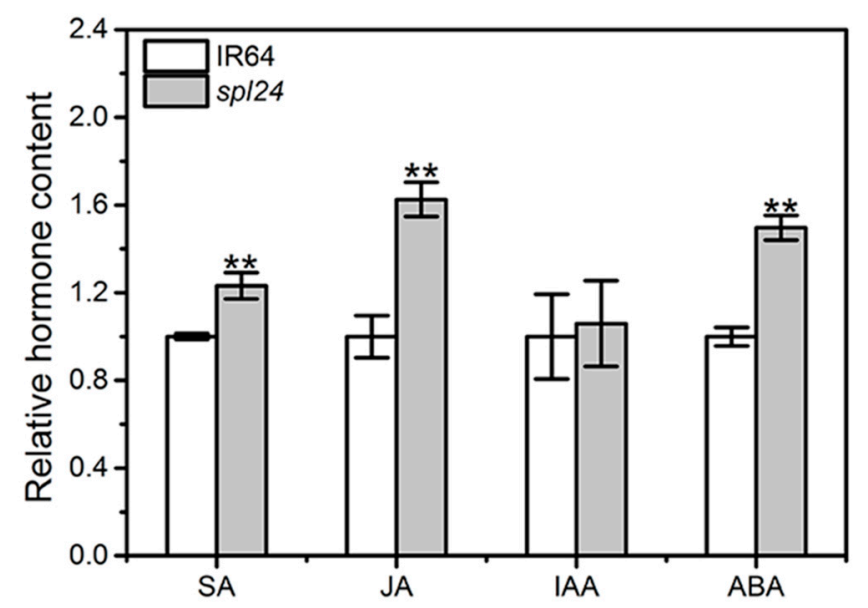

Figure 6. Plant hormone contents in spl24 and IR64. The level of plant hormone in IR64 was normalized to 1 . Values indicate means $\pm \operatorname{SD}(n=3)$. ${ }^{* *}$ denote $p \leq 0.01$ by Student's $t$ test.

\subsection{Genetic Control and Physical Mapping of OsSPL24}

To determine the genetic control of the spotted-leaf phenotype, spl24 was crossed with WT IR64. All $\mathrm{F}_{1}$ plants derived from spl24/IR64 showed brown lesions on the leaves but with reduced number of lesions, indicating that the lesion mimic trait was controlled by a dominant gene(s) with dosage effect or a semi-dominant gene(s). Furthermore, the $\mathrm{F}_{2}$ population including 239 individuals segregated into three categories: IR64-like type, intermediate type (similar to $\mathrm{F}_{1}$ ) and spl24-like type. The ratio of these three types fitted to a 1:2:1 $\left(\chi^{2}=0.78<\chi^{2}{ }_{0.05}=3.84\right)$, thus we concluded that the spotted-leaf phenotype was controlled by a single semi-dominant nuclear gene tentatively termed as Oryza sativa SPOTTED-LEAF 24 (OsSPL24).

To map OsSPL24 in the genome, we developed a large $\mathrm{F}_{2}$ population by crossing spl24 with Moroberekan, a normal green leaf japonica cultivar. Using the bulked segregant analysis approach, two simple sequence repeat (SSR) markers (RM5961, RM26908) (Figure 7A) on chromosome 11 were identified in co-segregation with the spotted-leaf phenotype of spl24. To fine map the gene, a total of $1386 \mathrm{WT}$ individual $\mathrm{F}_{2}$ plants were genotyped, and the mutation was finally delimited to a $110 \mathrm{~kb}$ interval flanked by the markers Indel 33 and Indel 12 (Figure 7B). 


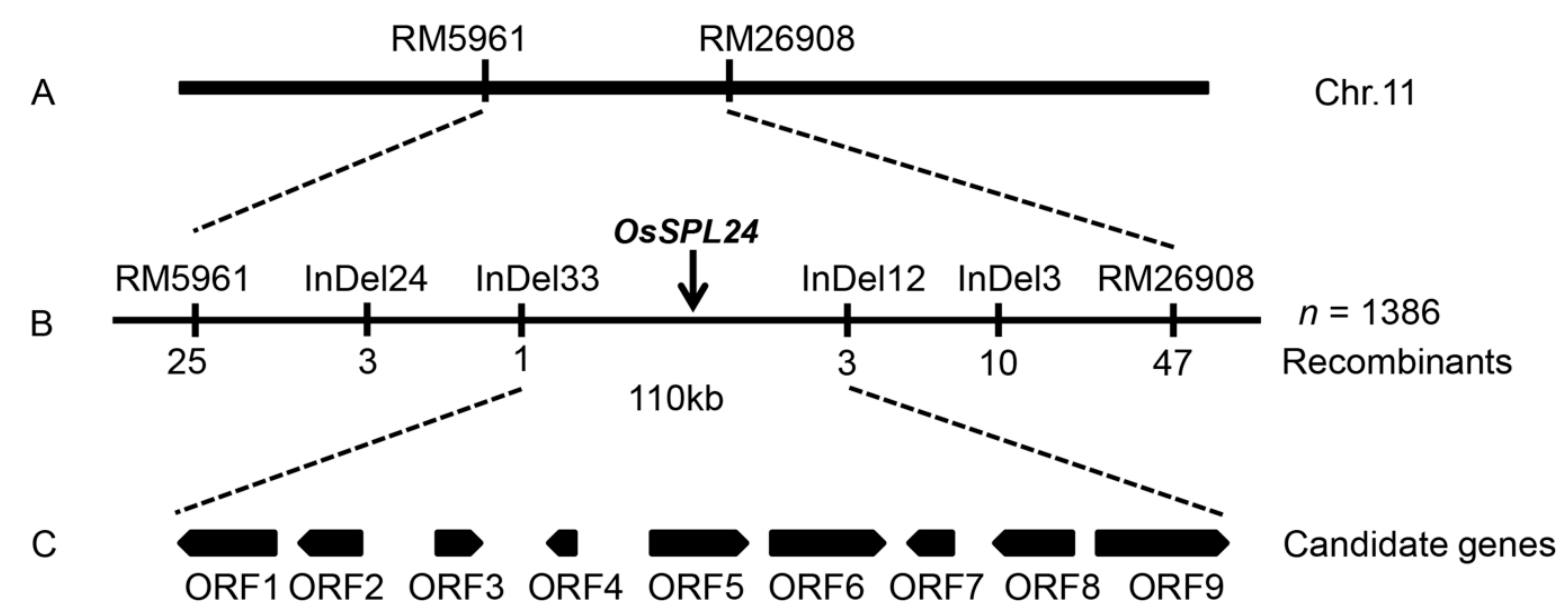

Figure 7. Location of the OsSPL24 gene on the long arm of chromosome 11.

Based on the Rice Genome Annotation Project (http:/ / rice.plantbiology.msu.edu/, accessed on 30-09-2018), 19 genes are found in the $110 \mathrm{~kb}$ target region, including nine putative open reading frames (ORFs) (Figure 7C and Table 3), 8 retrotransposon proteins and two transposon proteins. Identification of the target OsSPL24 responsible for the spotted-leaf phenotype is currently underway.

Table 3. The annotation of candidate genes.

\begin{tabular}{|c|c|c|}
\hline ORF & Gene ID & Annotation \\
\hline ORF1 & LOC_Os11g34460 & OsFBO10-F-box and other domain containing protein, expressed \\
\hline ORF2 & LOC_Os11g34470 & expressed protein \\
\hline ORF3 & LOC_Os11g34570 & lysM domain containing GPI-anchored protein precursor, putative, expressed \\
\hline ORF4 & LOC_Os11g34580 & $\begin{array}{l}\text { hypothetical protein } \\
\text { her }\end{array}$ \\
\hline ORF5 & LOC_Os11g34610 & DUF26 kinases have homology to DUF26 containing loci, expressed \\
\hline ORF6 & LOC_Os11g34624 & DUF26 kinases have homology to DUF26 containing loci, expressed \\
\hline ORF7 & LOC_Os11g34640 & expressed protein \\
\hline ORF8 & LOC_Os11g34650 & expressed protein \\
\hline ORF9 & LOC_Os11g34660 & Protease inhibitor/seed storage/LTP family protein precursor, expressed \\
\hline
\end{tabular}

\section{Discussion}

In the present study, we identified a novel spotted-leaf mutant (spl24) which was genetically controlled by a new single semi-dominant nuclear gene located to the long arm of chromosome 11 . The heterozygous $F_{1}$ plants exhibited a fewer brown lesions than that of WT, indicating the mutation had a dosage effect on the severity of the lesion symptom. Since both the WT and mutant alleles are functional and have the effect on the formation of lesion, thus spl24 belongs to a gain-of-function mutant. The spotted-leaf mutations usually impose significant variations on multiple agronomic traits such as the number of tillers [2] and plant height [37]. The mutant spl24 showed significantly decreased level of photosynthetic pigments and soluble proteins as well as the plant height, seed-setting rate, and 1000-grain weight. Therefore, the SPL24 mutation might directly affect the lesion formation and indirectly affect the performance of agronomic traits.

Besides genetic mutations, the initiation of lesions is also affected by multiple environmental factors including light, temperature, humidity, and mechanical wounding [38]. It has been shown that Arabidopsis thaliana lesion mimic mutant slh1 displays leaf lesions under the condition of low temperature and humidity [39], while the rice mutant M1009 does not show lesions when the temperature is higher than $25^{\circ} \mathrm{C}$; however, the lesions appears when the temperature is lower than $20^{\circ} \mathrm{C}$ [40], in contrast, the rice spl7 lesions are induced by high temperature $\left(>35^{\circ} \mathrm{C}\right)$ and ultra-violet solar irradiation [6]. The rice HM47 lesions are initiated under natural light [2]. Similar to HM47, the initiation of lesions in spl24 is also light-dependent. These conditional mutants indicate that some 
specific pathways such as chlorophyll metabolism and defense signaling pathways are associated with the formation of lesions. For example, the inactivation of pheophorbide an oxygenase, a key enzyme in chlorophyll degeneration pathway, is responsible for the lesion initiation in the sorghum lesion mimic mutant ded1 [41]. Determination of the specific pathway responsible for the lesion formation of spl24 has yet to be characterized.

The most prominent feature of the spotted-leaf mutants is the formation of hypersensitive response-like lesions, a form of PCD. It has been shown that cell death is detected in/around the lesions of spl11, HM47 and spl33 in rice using trypan blue staining [2,7,13]. In addition, the cell death is likely caused by the burst of ROS in the mutants mentioned above as well as the rice HM143 and sorghum ded1 [4,41]. In the present study, spl24 shows HR-like PCD with dosage effect. The spl24 cell death is associated with the degradation of nuclear acid indicated by TUNEL staining, the burst of $\mathrm{H}_{2} \mathrm{O}_{2}$ indicated by DAB staining and the altered expression of caspase-like genes. Furthermore, ROS is the product of redox reaction and the superfluous ROS is cleaned up by the reactive oxygen scavenging system including CAT, SOD and POD to prevent cells from their harmful effects [42]. In this study, the activity of CAT decreased significantly while the activities of POD and SOD increased apparently, leading to the high level of ROS accumulation and cell death in spl24. It is likely that the increased activities of POD and SOD are not enough for the compensation of the lowered CAT activity for excessive ROS degeneration. However, the reasons for the altered enzymatic activities remain elusive.

Many rice spotted-leaf mutants exhibit stronger levels of resistance than their WTs to bacterial and fungal pathogens [1]. The enhanced disease resistance is associated with the upregulation of various defense response genes [2,12]. It has been shown that endogenous SA level is increased apparently, preceding the induction of pathogenesis-related genes and the onset of disease resistance [43-45]. In this study, the endogenous level of SA in spl24 increased by $23.2 \%$ and the resistance of spl24 to 8 races of Xanthomonas oryzae pv. oryzae was significantly enhanced with the upregulation of multiple defense response genes, especially the genes involved in SA pathways were detected both by qRT-PCR and RNA-seq. Taken together, this led us to concluded that OsSPL24-mediated resistance was associated with the activation of SA signaling pathway. Unexpectedly, the level of JA in spl24 was significantly increased by $62.5 \%$; however, the upregulation of JA signaling pathway genes detected in qRT-PCR was not detected in RNA-seq analysis due to unknown reasons. Though the interaction between SA and JA is complicated while their antagonistic relationship is well accepted [46,47]. It has been shown that accumulation of both SA and JA is associated with enhanced resistance against Xoo in rice $[48,49]$. It is likely that multiple pathways that interact with each other are involved in host resistance to Xoo. Nevertheless, whether JA signaling is involved in OsSPL24-mediated resistance has yet to be determined. ABA is well known for its role in triggering plant senescence [50]. Interestingly, ABA treatment inhibits both upstream and downstream signaling in the SA-mediated defense pathway, independently of the jasmonic acid/ethylene-mediated signaling pathway [51]. It seems the increased level of endogenous ABA in spl24 did not inhibit the SA signaling as the upregulation of multiple SA-related genes was detected. Furthermore, based on the DEGs analysis, OsSPL24-mediated disease resistance was probably indirectly associated with multiple other pathways/components involved in vesicle trafficking, cell wall components, transcription factors, heat shock proteins and MAPK kinases. To elucidate the molecular mechanism of OsSPL24-mediated bacterial resistance, we are currently carrying out the map-based cloning to isolate the target gene.

\section{Materials and Methods}

\subsection{Plant Materials and Growth Conditions}

The indica rice spotted-leaf 24 (spl24) mutant was isolated from an ethyl methane sulfonate (EMS)-induced IR64 mutant bank [52]. The mutant, wild-type (WT) and $\mathrm{F}_{2}$ populations were grown in the paddy field in the summer of 2017 at the CNRRI in Hangzhou, Zhejiang, China. The $F_{2}$ 
population derived from the cross spl24/Moroberekan was used for genetic analysis and gene mapping. The backcrossed population derived from spl24/IR64 was used for high-throughput RNA sequencing analysis. The agronomic traits including plant height, number of tillers/plant, panicle length, number of filled grains/panicle, seed-setting rate and 1000-grain weight were recorded at the mature stage on three individual plants, and the means from three replicates were used for analysis.

\subsection{Senescence-related Parameter Measurement}

The upper leaves of the mutant spl24 and WT IR64 at the tillering and the heading stages were used to measure the contents of chlorophyll a $(\mathrm{Chl} \mathrm{a})$, chlorophyll b $(\mathrm{Chl} \mathrm{b})$ and carotenoid as described previously [53]. The activities of ROS scavenging enzymes, including peroxidase (POD), superoxide dismutase (SOD), and catalase (CAT), as well as the contents of malonaldehyde (MDA), hydrogen peroxide $\left(\mathrm{H}_{2} \mathrm{O}_{2}\right)$ and soluble proteins (SP), were determined at the heading stage following the manufacturer's instructions (Nanjing Jiancheng Bioengineering Institute, Nanjing, China). Membrane ion leakage was determined as described previously [54]. The means from three measurements were used for analysis.

\subsection{Shading Experiment}

When the lesions appeared on the tip of the leaves in spl24 at the early heading stage, the mutant leaves with and without lesions were shaded respectively with a piece of $2-3 \mathrm{~cm}$ aluminum foil for 3 days under natural light conditions. The foil was then removed, and light was reinstated for 4 days to investigate the influence of natural light on the initiation of lesions. Lesion development was documented by a scanner (HP scanner jet 4010, HP, Shanghai, China).

\subsection{Histochemical Analysis}

Leaves from WT and leaves with lesions from spl24 at the early heading stage were used to verify the cell death and $\mathrm{H}_{2} \mathrm{O}_{2}$ accumulation by trypan blue staining and 3,3'-diaminobenzidine (DAB) staining following the methods described previously $[55,56]$.

\subsection{TUNEL Experiment}

For the TUNEL assay, leaves with and without lesions from the mutant spl24 and the WT IR64 at the early heading stage were fixed by FAA solution ( $5 \%$ propionic acid, $40 \%$ formaldehyde and $50 \%$ ethanol) for $24 \mathrm{~h}$ at $4{ }^{\circ} \mathrm{C}$. The $9 \mu \mathrm{m}$ parafilm sections of treated leaves were used for TUNEL analysis. The DeadEnd Fluorometric TUNEL system was used for nuclear DNA fragmentation assay by using a Fluorescein in Situ Cell Death Detection Kit following the manufacturer's instructions (Roche, Basel, Switzerland). Samples were photographed using a confocal laser scanning microscope (Ceise, Jena, Germany).

\subsection{RNA Extraction and $q R T-P C R$}

Total RNA was isolated from the leaves at the early heading stage using NucleoZOL reagent (Macherey-Nagel, Düren, Germany), according to the manufacturer's instructions. RNA samples were treated with DNase (Promega, Madison, USA), and then $1 \mu \mathrm{g}$ of RNA was subsequently used to synthesize first-strand cDNA for reverse transcription-PCR. The quantitative real-time PCR (qRT-PCR) was performed in a total volume of $20 \mu \mathrm{L}$ reaction buffer containing $6 \mu \mathrm{L}$ cDNA template (120 ng), $10 \mu \mathrm{L}$ SYBR Premix E $\times$ Taq (Takara), $4 \mu \mathrm{L}$ primer $(10 \mu \mathrm{mol} / \mu \mathrm{L})$ on a Thermal Cycler Dice Real Time System II (Takara, Kusatsu, Japan) at $95^{\circ} \mathrm{C}$ pre-denaturation for $10 \mathrm{~min}$ and followed at $95^{\circ} \mathrm{C} 10 \mathrm{~s}$, $60{ }^{\circ} \mathrm{C} 30 \mathrm{~s}$, for 40 cycles, with a final dissociation at $95^{\circ} \mathrm{C} 15 \mathrm{~s}, 60^{\circ} \mathrm{C} 30 \mathrm{~s}, 95^{\circ} \mathrm{C} 15 \mathrm{~s}$. The rice ACTIN was used as the internal control to normalize the expression levels. The data were analyzed by the $2^{-\Delta \Delta C t}$ method and means from three replicates were used for analysis. The relevant primer sequences for defense response genes and OsMCs are listed in Table S1. 


\subsection{Disease Evaluation and Phytohormone Level Determination}

Rice plants of spl24, WT and susceptible control IR24 at the tillering stage were inoculated with 10 races (HB17, GD1358, PXO71, JS97-2, PXO112, Zhe173, OS-225, PXO339, PXO347 and PXO349) of Xanthomonas oryzae pv. oryzae (Xoo) by the leaf-clipping method [57]. The bacterial cultures were separately suspended in distilled water and adjusted to OD600 = 1.0 for inoculation. Five fully expanded-leaves per genotype were inoculated for each race. Lesion length was scored 20 days after inoculation. Means from five leaves were used for analysis. The levels of hormones including SA, JA, ABA, and IAA in spl24 and WT were determined following the method described previously [12].

\subsection{Genetic Analysis and Gene Mapping}

To determine the genetic control, spl24 was used as the female parent and crossed with the male parent IR64. The $F_{1}$ plants and $F_{2}$ individuals were grown in the paddy field at the CNRRI for phenotyping. To map the mutation, an $\mathrm{F}_{2}$ population was developed from the cross between spl24 and the normal green leaf cultivar Moroberekan. The bulked segregant analysis approach was adopted to rapidly locate the mutation to a chromosome and then fine mapping was carried out by genotyping the $\mathrm{WT} \mathrm{F}_{2}$ individuals. The DNA of the parents and $\mathrm{F}_{2}$ individual plants were extracted following the mini-preparation method [58]. SSR markers were obtained from the website (http:/ / www.gramene.org/) while insertion/deletion (InDel) markers were designed using the Primer 5.0 (PREMIER Biosoft, California, USA) and DNAStar 5.0 software (DNASTAR, Madison, USA) after comparison of the sequences between the japonica cultivar Nipponbare and the indica cultivar 9311 in the public database on the website (http:/ / gramene.org/genome_browser/index.html, accessed on 06-11-2013). PCR reaction and detection were carried out as described previously [2]. The primers were synthesized by Sangon Biotech Co. Ltd (Shanghai, China). The relevant SSR and InDel primer sequences for gene mapping are listed in Table S1.

\subsection{Transcriptome Analysis}

To eliminate other possible mutations presented in the mutant, spl24 was backcrossed to the wild-type IR64. The $\mathrm{F}_{2}$ plants were selfed to generate $\mathrm{BC}_{2} \mathrm{~F}_{2}$. Three individual $\mathrm{BC}_{2} \mathrm{~F}_{2}-\mathrm{S}$ (spl24-like type) and three $\mathrm{BC}_{2} \mathrm{~F}_{2}-\mathrm{W}$ (IR64-like type) plant at heading stage were chosen for isolation of total RNA. A total of 6 RNA samples were used for RNA-seq analyses. Library construction and an approximate 6G bp deep sequencing were carried out using the Illumina HiSeq 3000 platform (Illumina, San Diego, CA, USA) following the manufacturer's instructions by Vazyme biotech co, Ltd. (Nanjing, China). The aligned read files were processed by Cufflinks, which uses the normalized RNA-seq fragment counts to measure the relative abundances of the transcripts. The unit of measurement is Fragment Per Kilobase of exon per Million fragments mapped (FPKM). DEGs between the spl24 and IR64, based on three biological replicates of each, were identified using the Empirical Analysis of Digital Gene Expression data package in Cuffdiff (ver.2.1.1). An absolute fold change $\geq 2$ and an FDR significance score $\leq 0.05$ were used as thresholds to identify significant differences in gene expression. Each DEG was annotated, initially according to the top Oryza sativa and then by GO enrichment analysis, which was performed using GO Slim (http:/ / www.geneontology.org) (accessed on 14-10-2017), o assign it to the one of the three principal GO categories: molecular function, cellular component, and biological process. 
Supplementary Materials: Supplementary materials can be found at http:/ / www.mdpi.com/1422-0067/19/12/ $3766 /$ s1.

Author Contributions: Conceptualization, X.-b.Z. and J.-1.W.; Formal analysis, Z.C.; Funding acquisition, J.-1.W.; Investigation, Z.C., T.C. and A.P.S.; Methodology, X.-b.Z.; Supervision, Y.-q.H. and J.-1.W.; Writing - original draft, Z.C.; Writing - review \& editing, X.-b.Z. and J.-l.W.

Funding: This work was supported by the Ministry of Science and Technology of China (2016YFD0101104) and the State Key Laboratory of Rice Biology.

Conflicts of Interest: The authors declare no conflict of interest.

\section{References}

1. Huang, Q.N.; Yang, Y.; Shi, Y.F.; Wu, J.L. Spotted-leaf mutants of rice (Oryza sativa). Rice Sci. 2010, 17, $247-256$. [CrossRef]

2. Feng, B.H.; Yang, Y.; Shi, Y.F.; Shen, H.C.; Wang, H.M.; Huang, Q.N.; Xu, X.; Lü, X.G.; Wu, J.L. Characterization and genetic analysis of a novel rice spotted-leaf mutant $H M 47$ with broad-spectrum resistance to Xanthomonas oryzae pv. oryzae. J. Integr. Plant Biol. 2013, 55, 473-483. [CrossRef] [PubMed]

3. Huang, Q.N.; Shi, Y.F.; Yang, Y.; Feng, B.H.; Wei, Y.L.; Chen, J.; Baraoidan, M.; Leung, H.; Wu, J.L. Characterization and genetic analysis of a light-and temperature-sensitive spotted-leaf mutant in rice. J. Integr. Plant Biol. 2011, 53, 671-681. [CrossRef] [PubMed]

4. Shen, H.C.; Shi, Y.F.; Feng, B.H.; Wang, H.M.; Xu, X.; Huang, Q.N.; Lü, X.G.; Wu, J.L. Identification and genetic analysis of a novel rice spotted-leaf mutant with broad-spectrum resistance to Xanthomonas oryzae, pv. oryzae. J. Integr. Agric. 2014, 13, 713-721. [CrossRef]

5. Huang, Q.N.; Shi, Y.F.; Zhang, X.B.; Song, L.X.; Feng, B.H.; Wang, H.M.; Xu, X.; Li, X.H.; Guo, D.; Wu, J.L. Single base substitution in $O s C D C 48$ is responsible for premature senescence and death phenotype in rice. J. Integr. Plant Biol. 2016, 58, 12-28. [CrossRef] [PubMed]

6. Yamanouchi, U.; Yano, M.; Lin, H.; Ashikari, M.; Yamada, K. A rice spotted leaf gene, Spl7, encodes a heat stress transcription factor protein. Proc. Natl. Acad. Sci. USA. 2002, 99, 7530-7535. [CrossRef] [PubMed]

7. Zeng, L.R.; Qu, S.; Bordeos, A.; Yang, C.; Baraoidan, M.; Yan, H.; Xie, Q.; Nahm, B.H.; Leung, H.; Wang, G.L. Spotted leaf 11, a negative regulator of plant cell death and defense, encodes a U-box/armadillo repeat protein endowed with E3 ubiquitin ligase activity. Plant Cell 2004, 16, 2795-2808. [CrossRef] [PubMed]

8. Wang, L.; Pei, Z.; Tian, Y.; He, C. OsLSD1, a rice zinc finger protein, regulates programmed cell death and callus differentiation. Mol. Plant Microbe Interact. 2005, 18, 375-384. [CrossRef] [PubMed]

9. Chern, M.; Fitzgerald, H.A.; Canlas, P.E.; Navarre, D.A.; Ronald, P.C. Overexpression of a rice NPR1 homolog leads to constitutive activation of defense response and hypersensitivity to light. Mol. Plant Microbe Interact. 2005, 18, 511-520. [CrossRef] [PubMed]

10. Yuan, Y.; Zhong, S.; Li, Q.; Zhu, Z.; Lou, Y.; Wang, L.; Wang, J.; Wang, M.; Li, Q.; Yang, D.; et al. Functional analysis of rice NPR1-like genes reveals that OsNPR1/NH1 is the rice orthologue conferring disease resistance with enhanced herbivore susceptibility. Plant Biotechnol. J. 2007, 5, 313-324. [CrossRef] [PubMed]

11. Tang, J.; Zhu, X.; Wang, Y.; Liu, L.; Xu, B.; Li, F.; Fang, J.; Chu, C. Semi-dominant mutations in the CC-NB-LRR-type R gene, NLS1, lead to constitutive activation of defense responses in rice. Plant J. 2011, 66, 996-1007. [CrossRef] [PubMed]

12. Zhang, X.B.; Feng, B.H.; Wang, H.M.; Xu, X.; Shi, Y.F.; He, Y.; Chen, Z.; Sathe, A.P.; Shi, L.; Wu, J.L. A substitution mutation in OsPELOTA confers bacterial blight resistance by activating the salicylic acid pathway. J. Integr. Plant Biol. 2018, 60, 160-172. [CrossRef] [PubMed]

13. Wang, S.; Lei, C.L.; Wang, J.L.; Ma, J.; Tang, S.; Wang, C.L.; Zhao, K.J.; Tian, P.; Zhang, H.; Qi, C.Y.; et al. SPL33, encoding an eEF1A-like protein, negatively regulates cell death and defense responses in rice. J. Exp. Bot. 2017, 68, 899-913. [CrossRef] [PubMed]

14. Chen, X.; Pan, J.; Cheng, J.; Jiang, G.; Jin, Y.; Gu, Z.; Zhai, W.X.; Ma, B.J. Fine genetic mapping and physical delimitation of the lesion mimic gene spotted leaf 5 (spl5) in rice (Oryza sativa L.). Mol. Breed. 2009, 24, 387-395. [CrossRef]

15. Chen, X.; Hao, L.; Pan, J.; Zheng, X.; Jiang, G.; Jin, Y.; Gu, Z.M.; Qian, Q.; Zhai, W.X. Spl5, a cell death and defense-related gene, encodes a putative splicing factor $3 \mathrm{~b}$ subunit 3 (sf3b3) in rice. Mol. Breed. 2012, 30, 939-949. [CrossRef] 
16. Lorrain, S.; Lin, B.; Auriac, M.C.; Kroj, T.; Saindrenan, P.; Nicole, M.; Balagué, C.; Roby, D. VASCULAR ASSOCIATED DEATH1, a novel GRAM domain-containing protein, is a regulator of cell death and defense responses in vascular tissues. Plant Cell. 2004, 16, 2217-2232. [CrossRef] [PubMed]

17. Noutoshi, Y.; Kuromori, T.; Wada, T.; Hirayama, T.; Kamiya, A.; Imura, Y.; Yasuda, M.; Nakashita, H.; Shirasu, K.; Shinozaki, K. Loss of NECROTIC SPOTTED LESIONS 1 associates with cell death and defense responses in Arabidopsis thaliana. Plant Mol. Biol. 2006, 62, 29-42. [CrossRef] [PubMed]

18. Mosher, S.; Moeder, W.; Nishimura, N.; Jikumaru, Y.; Joo, S.H.; Urquhart, W.; Klessig, D.F.; Kim, S.K.; Nambara, E.; Yoshioka, K. The lesion-mimic mutant cpr22 shows alterations in abscisic acid signaling and abscisic acid insensitivity in a salicylic acid-dependent manner. Plant Physiol. 2010, 152, 1901-1913. [CrossRef] [PubMed]

19. Qiao, Y.; Jiang, W.; Lee, J.H.; Park, B.S.; Choi, M.S.; Piao, R.; Woo, M.O.; Roh, J.H.; Han, L.; Paek, N.C.; et al. SPL28 encodes a clathrin-associated adaptor protein complex 1 , medium subunit $\mu 1$ (AP1M1) and is responsible for spotted leaf and early senescence in rice (Oryza sativa). New Phytol. 2010, 185, 258-274. [CrossRef] [PubMed]

20. Gray, J.; Close, P.S.; Briggs, S.P.; Johal, G.S. A novel suppressor of cell death in plants encoded by the Lls1 gene of maize. Cell 1997, 89, 25-31. [CrossRef]

21. Yang, M.; Wardzala, E.; Johal, G.S.; Gray, J. The wound-inducible Lls1 gene from maize is an orthologue of the Arabidopsis Acd1 gene, and the LLS1 protein is present in non-photosynthetic tissues. Plant Mol. Biol. 2004, 54, 175-191. [CrossRef] [PubMed]

22. Mori, M.; Tomita, C.; Sugimoto, K.; Hasegawa, M.; Hayashi, N.; Dubouzet, J.G.; Ochiai, H.; Sekimoto, H.; Hirochika, H.; Kikuchi, S. Isolation and molecular characterization of a Spotted leaf 18 mutant by modified activation-tagging in rice. Plant Mol. Biol. 2007, 63, 847-860. [CrossRef] [PubMed]

23. Wang, S.H.; Lim, J.H.; Kim, S.S.; Cho, S.H.; Yoo, S.C.; Koh, H.J.; Sakuraba, Y.; Paek, N.C. Mutation of SPOTTED LEAF3 (SPL3) impairs abscisic acid-responsive signaling and delays leaf senescence in rice. J. Exp. Bot. 2015, 66, 7045-7059. [CrossRef] [PubMed]

24. Kim, J.A.; Cho, K.; Singh, R.; Jung, Y.H.; Jeong, S.H.; Kim, S.H.; Lee, J.E.; Cho, Y.S.; Agrawal, G.K.; Rakwal, R.; et al. Rice OsACDR1 (Oryza sativa accelerated cell death and resistance 1) is a potential positive regulator of fungal disease resistance. Mol. Cells 2009, 28, 431-439. [CrossRef] [PubMed]

25. Fujiwara, T.; Maisonneuve, S.; Isshiki, M.; Mizutani, M.; Chen, L.; Wong, H.L.; Kawasaki, T.; Shimamoto, K. Sekiguchi lesion gene encodes a cytochrome P450 monooxygenase that catalyzes conversion of tryptamine to serotonin in rice. J. Biol. Chem. 2010, 285, 11308-11313. [CrossRef] [PubMed]

26. Fekih, R.; Tamiru, M.; Kanzaki, H.; Abe, A.; Yoshida, K.; Kanzaki, E.; Saitoh, H.; Takagi, H.; Natsume, S.; Undan, J.R.; et al. The rice (Oryza sativa L.) LESION MIMIC RESEMBLING, which encodes an AAA-type ATPase, is implicated in defense response. Mol. Genet. Genom. 2015, 290, 611-622. [CrossRef] [PubMed]

27. Liu, Q.; Ning, Y.; Zhang, Y.; Yu, N.; Zhao, C.; Zhan, X.; Wu, W.; Chen, D.; Wei, X.; Wang, G.L.; et al. OsCUL3a negatively regulates cell death and immunity by degrading OsNPR1 in rice. Plant Cell 2017, 29, 345-359. [CrossRef] [PubMed]

28. Undan, J.R.; Tamiru, M.; Abe, A.; Yoshida, K.; Kosugi, S.; Takagi, H.; Yoshida, K.; Kanzaki, H.; Saitoh, H.; Fekih, R.; et al. Mutation in OsLMS, a gene encoding a protein with two double-stranded RNA binding motifs, causes lesion mimic phenotype and early senescence in rice (Oryza sativa L.). Genes Genet. Syst. 2012, 87, 169-179. [CrossRef] [PubMed]

29. Wu, C.; Bordeos, A.; Madamba, M.R.; Baraoidan, M.; Ramos, M.; Wang, G.L.; Leach, J.E.; Leung, H. Rice lesion mimic mutants with enhanced resistance to diseases. Mol. Genet. Genom. 2008, 279, 605-619. [CrossRef] [PubMed]

30. Jung, Y.H.; Lee, J.H.; Agrawal, G.K.; Rakwal, R.; Kim, J.A.; Shim, J.K.; Lee, S.K.; Jeon, J.S.; Koh, H.J.; Lee, Y.H.; et al. The rice (Oryza sativa) Blast Lesion Mimic Mutant, blm, may confer resistance to blast pathogens by triggering multiple defense-associated signaling pathways. Plant Physiol. Biochem. 2005, 43, 397-406. [CrossRef] [PubMed]

31. Munnebosch, S.; Alegre, L. Review: Die and let live: Leaf senescence contributes to plant survival under drought stress. Funct. Plant Biol. 2004, 31, 8808-8818. [CrossRef]

32. Wang, J.; Ye, B.; Yin, J.; Yuan, C.; Zhou, X.; Li, W.; He, M.; Wang, J.; Chen, W.; Qin, P.; et al. Characterization and fine mapping of a light-dependent leaf lesion mimic mutant 1 in rice. Plant Physiol. Biochem. 2015, 97, 44-51. [CrossRef] [PubMed] 
33. Miller, G.; Suzuki, N.; Ciftci-Yilmaz, S.; Mittler, R. Reactive oxygen species homeostasis and signaling during drought and salinity stresses. Plant Cell Environ. 2010, 33, 453-467. [CrossRef] [PubMed]

34. Huang, L.; Zhang, H.; Hong, Y.; Liu, S.; Li, D.; Song, F. Stress-responsive expression, subcellular localization and protein-protein interactions of the rice metacaspase family. Int. J. Mol. Sci. 2015, 16, 16216-16241. [CrossRef] [PubMed]

35. Stegmann, M.; Anderson, R.G.; Ichimura, K.; Pecenkova, T.; Reuter, P.; Žársky, V.; McDowell, J.M.; Shirasu, K.; Trujillo, M. The ubiquitin ligase PUB22 targets a subunit of the exocyst complex required for PAMP-triggered responses in Arabidopsis. Plant Cell 2012, 24, 4703-4716. [CrossRef] [PubMed]

36. Wang, D.; Weaver, N.D.; Kesarwani, M.; Dong, X. Induction of protein secretory pathway is required for systemic acquired resistance. Science 2005, 308, 1036-1040. [CrossRef] [PubMed]

37. Takahashi, A.; Kawasaki, T.; Henmi, K.; ShiI, K.; Kodama, O.; Satoh, H.; Shimamoto, K. Lesion mimic mutants of rice with alterations in early signaling events of defense. Plant J. 1999, 17, 535-545. [CrossRef] [PubMed]

38. Campbell, M.A.; Ronald, P.C. Characterization of four rice mutants with alterations in the defence response pathway. Mol. Plant Pathol. 2005, 6, 11-21. [CrossRef] [PubMed]

39. Noutoshi, Y.; Ito, T.; Seki, M.; Nakashita, H.; Yoshida, S.; Marco, Y.; Shirasu, K.; Shinozaki, K. A single amino acid insertion in the WRKY domain of the Arabidopsis TIR-NBS-LRR-WRKY-type disease resistance protein SLH1 (sensitive to low humidity 1) causes activation of defense responses and hypersensitive cell death. Plant J. 2005, 43, 873-888. [CrossRef] [PubMed]

40. Arase, S.; Zhao, C.M.; Akimitsu, K.; Yamamoto, M.; Ichii, M. A recessive lesion mimic mutant of rice with elevated resistance to fungal pathogens. J. Pant Pathol. 2000, 66, 109-116. [CrossRef]

41. Sindhu, A.; Janick-Buckner, D.; Buckner, B.; Gray, J.; Zehr, U.; Dilkes, B.P.; Johal, G.S. Propagation of cell death in dropdead1, a sorghum ortholog of the maize lls1 mutant. PLoS ONE 2018, 13, e0201359. [CrossRef] [PubMed]

42. Jacks, T.J.; Davidonis, G.H. Superoxide, hydrogen peroxide, and the respiratory burst of fungally infected plant cells. Mol. Cell. Biochem. 1979, 158, 77-79. [CrossRef]

43. Shah, J.; Kachroo, P.; Nandi, A.; Klessig, D.F. A recessive mutation in the Arabidopsis SSI2 gene confers SAand NPR1-independent expression of $P R$ genes and resistance against bacterial and oomycete pathogens. Plant J. 2001, 25, 563-574. [CrossRef] [PubMed]

44. Prithiviraj, B.; Bais, H.P.; Jha, A.K.; Vivanco, J.M. Staphylococcus aureus pathogenicity on Arabidopsis thaliana is mediated either by a direct effect of salicylic acid on the pathogen or by SA-dependent, NPR1-independent host responses. Plant Ji 2005, 42, 417-432. [CrossRef] [PubMed]

45. Yang, W.; Xu, X.N.; Li, Y.; Wang, Y.Z.; Li, M.; Wang, Y.; Ding, X.H.; Chu, Z.H. Rutin-mediated priming of plant resistance to three bacterial pathogens initiating the early SA signal pathway. PLOS ONE 2016, 11, e0146910. [CrossRef] [PubMed]

46. Kunkel, B.N.; Brooks, D.M. Cross talk between signaling pathways in pathogen defense. Curr. Opin. Plant Biol. 2002, 5, 325-331. [CrossRef]

47. He, X.; Jiang, J.S.; Wang, C.Q.; Dehesh, K. ORA59 and EIN3 interaction couples jasmonate-ethylene synergistic action to antagonistic salicylic acid regulation of PDF expression. J. Integr. Plant Biol. 2017, 59, $275-287$. [CrossRef] [PubMed]

48. Tao, Z.; Liu, H.; Qiu, D.; Zhou, Y.; Li, X.; Xu, C.; Wang, S. A pair of allelic WRKY genes play opposite role in rice-bacteria interactions. Plant Physiol. 2009, 151, 936-948. [CrossRef] [PubMed]

49. Shen, X.; Liu, H.; Yuan, B.; Li, X.; Xu, C.; Wang, S. OsEDR1 negatively regulates rice bacterial resistance via activation of ethylene biosynthesis. Plant Cell Environ. 2011, 34, 179-191. [CrossRef] [PubMed]

50. Cutler, S.R.; Rodriguez, P.L.; Finkelstein, R.R.; Abrams, S.R. Abscisic acid: Emergence of a core signaling network. Annu. Rev. Plant Biol. 2010, 61, 651-679. [CrossRef] [PubMed]

51. Yasuda, M.; Ishikawa, A.; Jikumaru, Y.; Seki, M.; Umezawa, T.; Asami, T.; Maruyama-Nakashita, A.; Kudo, T.; Shinozaki, K.; Yoshida, S.; et al. Antagonistic interaction between systemic acquired resistance and the abscisic acid-mediated abiotic stress response in Arabidopsis. Plant Cell 2008, 20, 1678-1692. [CrossRef] [PubMed]

52. Wu, J.L.; Wu, C.; Lei, C.; Baraoidan, M.; Bordeos, A.; Madamba, M.R.; Ramos-Pamplona, M.; Mauleon, R.; Portugal, A.; Ulat, V.J.; et al. Chemical- and irradiation-induced mutants of indica rice IR64 for forward and reverse genetics. Plant Mol. Biol. 2005, 59, 85-97. [CrossRef] [PubMed] 
53. Wellburn, A.R. The spectral determination of chlorophylls $a$, and $b$, as well as total carotenoids, using various solvents with spectrophotometers of different resolution. J. Plant Physiol. 1994, 144, 307-313. [CrossRef]

54. He, Y.; Zhang, Z.H.; Li, L.J.; Tang, S.Q.; Wu, J.-L. Genetic and physio-biochemical characterization of a novel premature senescence leaf mutant in rice (Oryza sativa L.). Int. J. Mol. Sci. 2018, 19, 2339. [CrossRef] [PubMed]

55. Yin, Z.; Chen, J.; Zeng, L.; Goh, M.; Leung, H.; Khush, G.S.; Wang, G.L. Characterizing rice lesion mimic mutants and identifying a mutant with broad-spectrum resistance to rice blast and bacterial blight. Mol. Plant Microbe Interact. 2000, 13, 869-876. [CrossRef] [PubMed]

56. Thordal-Christensen, H.; Zhang, Z.G.; Wei, Y.D.; Collinge, D.B. Subcellular localization of $\mathrm{H}_{2} \mathrm{O}_{2}$ in plants. $\mathrm{H}_{2} \mathrm{O}_{2}$ accumulation in papillae and hypersensitive response during the barley-powdery mildew interaction. Plant J. 1997, 11, 1187-1194. [CrossRef]

57. Kauffman, H.E. An improved technique for evaluating resistance of rice varieties to Xanthomonas oryzae. Plant Dis. Rep. 1973, 57, 537-541.

58. Lu, Y.J.; Zheng, K.L. A simple method for DNA extraction in rice. Chin. J. Rice Sci. 1992, 6, 47-48, (In Chinese with an English abstract).

(C) 2018 by the authors. Licensee MDPI, Basel, Switzerland. This article is an open access article distributed under the terms and conditions of the Creative Commons Attribution (CC BY) license (http:/ / creativecommons.org/licenses/by/4.0/). 